\title{
Taxonomy and morphology of Thalictrum (Ranunculaceae) in New Guinea
}

\author{
Renata Borosova $^{1}$ (D) Timothy M. A. Utteridge ${ }^{1}$ \& André Schuiteman ${ }^{1}$
}

Summary. The genus Thalictrum L. in New Guinea is revised based on morphological evidence. Full descriptions of the genus and the four taxa recognised are given. Two species are recognised: Thalictrum papuanum, widespread across New Guinea, and a new species described here; T. umbraticola, endemic to west New Guinea. Two new varieties are described: Thalictrum papuanum var. acutisegmentum and T. papuanum var. laticarpellum. One new synonym of Thalictrum papuanum var. papuanum is established: T. papuanum var. oranjense. Keys to the taxa and distribution maps, as well as preliminary conservation assessments, are provided.

Key Words. Conservation, Indonesia, IUCN, Malesia, new species, systematics.

\section{Introduction}

Ranunculaceae are a cosmopolitan family that includes many well-known temperate wildflowers and ornamental plants, including buttercups, hellebores and anemones, as well as several pharmaceutically important taxa. According to the Plants of the World Online (POWO 2019), there are 52 accepted genera and 3766 accepted species of Ranunculaceae. The family is distributed almost worldwide but is most diverse in temperate and colder regions; it is relatively rare in the tropics (Culham 2007). Ranunculaceae are thought to have originated in montane temperate areas of the northern hemisphere (Ziman \& Keener 1989). The family shows a wide variation in morphological characters, especially in floral organisation and fruit types (Tamura 1995). In New Guinea, three genera are present: Clematis L., Ranunculus L. and Thalictrum L. (Cámara-Leret et al. 2020). Ranunculaceae of Malesia have been revised by Eichler (1958), and the alpine species have been treated by van Royen (1982) and more recently in Utteridge (2006). Most species occur at high elevations; for example, in a checklist of Mt Trikora, Mangen (1993) documented 16 species of Ranunculaceae, with 14 taxa above and only two taxa below $3000 \mathrm{~m}$.

As part of ongoing research into the plant diversity and conservation of New Guinea at the Royal Botanic Gardens, Kew, the genera of Ranunculaceae on the island are being revised as the first stage towards a Flora Malesiana account. As part of this work, a revision of Thalictrum is presented here. Upon investigation it was found that the existing species, Thalictrum papuanum, did not fit all the material examined during this work. To account for all the variation, a new species was described as well as two further varieties.

The genus Thalictrum was first described by Linnaeus (1753: 545) and is considered one of the most diverse genera in the family in terms of the number of species and their morphological variation (Tamura 1995). It has $\mathrm{T}(=$ Thalictrum)-type chromosomes with the basic chromosome number $\mathrm{x}=7$ (Tamura 1993) and is included in the subfamily Thalictroideae (Wang et al. 2009). Thalictrum has great medicinal value as several species contain high levels of an anti-tumour drug, Thaliblastin (Thalicarpine) (Chen et al. 1993; Pajeva et al. 2004). All seeds of Thalictrum species investigated so far contain four unusual and diagnostically important fatty acids; two of these are the same as in Aquilegia L., whereas two have not been found in any other genus in Ranunculaceae (Aitzetmüller 1994). Comprising over 200 species (POWO 2019), Thalictrum is distributed in Eurasia, Americas, Africa and New Guinea (Mabberley 2008; Stevens 2001 onwards). In New Guinea it is represented by four endemic taxa (two species and two varieties).

\section{Materials and Methods}

Herbarium material and especially types deposited at B, BM, BO, CANB, E (online), GH, K, L, LAE, LUX (online), MU, P (online) and SING (online) were examined. Herbarium acronyms follow Index Herbariorum (Thiers, continuously updated). All cited specimens have been seen by the first author. Material was examined under a Leica M165 C binocular microscope at maximum magnification.

\footnotetext{
Accepted for publication 19 April 2021. Published online 17 September 2021

1 Royal Botanic Gardens, Kew, Richmond, Surrey, TW9 3AE, UK. e-mail: r.borosova@kew.org
} 
Nomenclatural practice follows Turland et al. (2018). Characters listed in the protologues and descriptions were compared to those present in herbarium material. Morphological terms follow Beentje (2016). Localities were manually georeferenced using locality information from herbarium specimens, paper maps and electronic gazetteers. Maps were made using Simple Mappr (Shorthouse 2010) with additional layers showing countries and relief. Assessment of conservation status was implemented using GeoCAT (Bachman et al. 2011) and follows the IUCN (2012) criteria.

\section{Taxonomic Treatment}

Thalictrum L. (Linnaeus 1753: 545); Linnaeus (1754: 242); van Royen (1982: 1293 - 1294); Riedl \& Nasir (1991: 95 - 111); Riedl (1992); Akeroyd (1993: 290 - 292); Rau (1993: 132 - 143); Tamura (1993: 581 - 582); Tamura (1995: 474 - 475); Park \& Festerling (1997: 258 - 271); Stace (1997: 95); Fu \& Zhu (2001: 282); Park \& Park (2008: 433 - 458, 2009: 89 - 99); Tamura (2011: 68); Soza et al. (2012: 180 - 192); Wang (2018: 56 - 57). Type: Thalictrum foetidum L. (Linnaeus 1753: 545; see Jarvis 1993: 883 - 884).

Perennial herbs; glabrous, sometimes puberulous or with glandular hairs. Roots fibrous, sometimes tuberous. Stems often sulcate and branched, glabrous, sometimes glandular. Petioles sheathing at base. Leaves basal and cauline, usually stipulate, $1-4$ pinnate or ternate, rarely simple; basal leaves few to several, sometimes withered at flowering, petiolate; cauline leaves alternate, rarely opposite or verticillate, petiolate or sessile. Leaflets cordate to reniform, obovate, lanceolate to linear; margin lobed or crenate. Inflorescence terminal, occasionally also axillary, a cyme, a raceme or a panicle, sometimes reduced to a single flower. Bracts $1-2$ (- 3), leaflike or absent. Flowers small, bisexual, rarely unisexual, actinomorphic. Sepals (3-) 4-5 (-10), petaloid, flat, white, yellowish-green, pink or purple, reniform or spathulate to lanceolate, 1 - $18 \mathrm{~mm}$ long, caducous in fruit. Petals absent. Stamens 5 - many, usually more conspicuous than sepals; filaments linear, filiform to clavate or dilated above; anthers lateral, oblong to linear. Carpels free, 1-ovulate; style straight or hooked, usually persistent; stigma linear or deltoid. Fruit a head of achenes; achenes free, not to strongly compressed on both sides, body 1 3-ribbed on lateral sides, sessile or stipitate; persistent style short or long, straight, hooked to circinate (description includes taxa from outside New Guinea).

DISTRIBUTION. About 190 species, worldwide, mainly in temperate regions; two species in New Guinea.

\section{Key to the species of Thalictrum in New Guinea}

Herbs $4-30 \mathrm{~cm}$ tall. Petiole of cauline leaves $1-10 \mathrm{~mm}$, petiolule of cauline leaves $1-5 \mathrm{~mm}$. Inflorescence $1-3$ (-4)-flowered. Achenes $3-5.5 \times 0.5-1.5 \mathrm{~mm}$, 3-ribbed. Elevation $2300-4000 \mathrm{~m} \ldots \ldots$. . . 1. T. papuanum Herbs (20 -) $25-45 \mathrm{~cm}$ tall. Petiole of cauline leaves $13-23 \mathrm{~mm}$ long, petiolule of cauline leaves $5-15 \mathrm{~mm}$. Inflorescence 4 -6-flowered. Achenes 3.5 - 5.5 ×0.5 mm, 1 - 2-ribbed. Elevation $1200-1300 \mathrm{~m} \ldots \ldots \ldots \ldots \ldots \ldots \ldots$ 2. T. umbraticola

1. Thalictrum papuanum Ridl. (Ridley 1916: 10); Eichler (1958: 6 - 7); van Royen (1982: 1294 - 1296); Tamura (1995: 487); Utteridge (2006: 416 - 418).

For type and synonyms see varieties.

Glabrous herb, $4-30 \mathrm{~cm}$ tall. Roots fibrous, rhizome slender. Stems erect, simple or occasionally branched. Basal leaves 1 9, blades $(0.8-) 1.5-3 \times(0.5-) 1-2.5(-3) \mathrm{cm}$, biternate with 9 leaflets or sometimes tri-foliolate; petiole $(1-) 1.5-6$ $(-8) \mathrm{cm}$; rachis $(0.2-) 1-2.5 \mathrm{~cm}$ long; petiolule $0.1-1 \mathrm{~cm}$ long or leaflets sessile; terminal leaflet broadly elliptic, ovate to rhombic-ovate or suborbicular, (2.5 -) 3-15 × $3-$ 15 mm, 3 - 7-lobed, sometimes lobes crenate. Cauline leaves $1-2$, alternate, tri-foliolate, biternate with 9 leaflets or simple; petiole $1-10 \mathrm{~mm}$; rachis (1 -) $2-5 \mathrm{~mm}$; petiolule (0.5 -) $1-5 \mathrm{~mm}$ long; terminal leaflet broadly elliptic to orbicular ovate, $3-9(-13) \times 3-11(-12) \mathrm{mm}, 3-5(-7)$ lobed, prominently palmately veined, base rounded, sometimes cuneate to subcordate, apex sharply acuminate, mucronate to mucronulate, sometimes rounded, margin usually revolute. Inflorescence racemose, 2 - 3 (-4)-flowered, often reduced to a single flower; peduncle up to $6 \mathrm{~cm}$ long, sometimes slender and purple distally with white corms; pedicel erect or slightly recurved, $(0.2-) 0.5-2(-3) \mathrm{cm}$ long. Bracts 1 - 2, simple, leaf-like, $1-5 \mathrm{~mm}$ long, ovate to lanceolate, entire or 1 - 3-lobed, shortly petiolate. Flowers bisexual, $4-8(-10) \mathrm{mm}$ across. Sepals $4-5$, ovate to elliptic, $2-3 \times 1-2 \mathrm{~mm}$, white, purple or pink. Stamens 5 - 25; filaments white, pink to purplish, $(1.5-) 2.5-3$ $(-3.5) \times(0.25-) 0.5-1 \mathrm{~mm}$, widest in the top third, base filiform, apex narrowly linear, narrower than anther. Anther $0.4-0.9 \times 0.2-0.5 \mathrm{~mm}$, obtuse at apex, connectives not projected. Carpels $6-14$, erect, $2-4.5 \times 0.5-1.1 \mathrm{~mm}$, fusiform; at base $0.5-1.5 \mathrm{~mm}$ stipitate; style circinnately coiled inwards, (0.4-) $0.7-1.4 \mathrm{~mm}$ long; stigmatic surface along distal (0.3-) $0.5-1 \mathrm{~mm}$ of the style. Achenes $6-14$, erect at first, later curving downwards, light purple to deep 
pink, fusiform, falcate or obovate to lanceolate, compressed to strongly compressed, $(2.3-) 3-5.5 \times 0.5-1.5 \mathrm{~mm}$, body 3-ribbed, dorsal suture straight or slightly convex or concave, ventral suture strongly convex, at base $(0.5-) 1-$ $2.2 \mathrm{~mm}$ stipitate; style $(0.5-) 1-2 \mathrm{~mm}$ long, circinnately coiled inwards.

\section{Key to varieties:}

1. Herbs $10-13 \mathrm{~cm}$ tall. Cauline leaves usually biternate with 9 leaflets. Leaflets sharply acuminate to mucronate at apex. Inflorescence 3 (-4)-flowered. Achenes $0.5-0.8 \mathrm{~mm}$ wide. Elevation $2300 \mathrm{~m}$............ b. var. acutisegmentum

Herbs $4-30 \mathrm{~cm}$ tall. Cauline leaves tri-foliolate or biternate with 9 leaflets. Leaflets mucronulate at apex. Inflorescence $1-2$

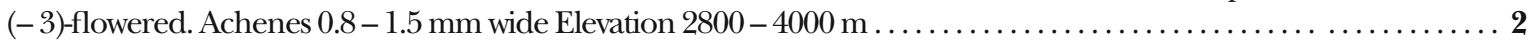

2. Herbs $5-7 \mathrm{~cm}$ tall. Petiole of basal leaves $(1-) 1.5-3(-4) \mathrm{cm}$. Cauline leaves usually biternate with 9 leaflets. Terminal leaflets of basal and cauline leaves the same size $3-6 \times 3-6 \mathrm{~mm}$. Achenes obovate to lanceolate, up to $1 \mathrm{~mm}$ stipitate.

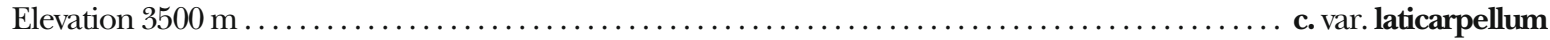

Herbs $4-30 \mathrm{~cm}$ tall. Petiole of basal leaves $(1-) 2-6(-8) \mathrm{cm}$. Cauline leaves usually tri-foliolate. Terminal leaflets of basal leaves larger than terminal leaflets of cauline leaves. Achenes falcate, at base $(0.5-) 1-$ $1.8 \mathrm{~mm}$ stipitate. Elevation $2800-4000 \mathrm{~m} \ldots \ldots \ldots \ldots \ldots \ldots \ldots \ldots \ldots \ldots \ldots \ldots \ldots$ a. var. panum

Thalictrum papuanum Ridl. var. papuanum (Ridley 1916: 10). Type: [Indonesia. Papua Province: Mt Jaya], Camp XIII - XIV, 13 Jan. 1913, Kloss s.n. (holotype $\mathrm{BM}$ !; isotype $\mathrm{K}$ !).

Thalictrum papuanum var. oranjense H.Eichler (1958: 7) synon. nov. Type: Indonesia. Papua Province: Oranje Mountains, Waterval biwak, 12 Feb. 1913, Versteeg 2474 (holotype L!; isotype BO!).

Herb, $4-30 \mathrm{~cm}$ tall. Basal leaves 1 - 8, blades (0.8 -) $1.5-$ $2.5 \times(0.5-) 1-2.5 \mathrm{~cm}$, biternate with 9 leaflets or sometimes tri-foliolate; petiole $(1-) 2-6(-8) \mathrm{cm}$; rachis $(0.2-) 1-2.5 \mathrm{~cm}$; petiolule $1-10 \mathrm{~mm}$ or leaflets sessile; terminal leaflet broadly elliptic, ovate or suborbicular, (2.5 -) $10-15 \times(3-) 8-15 \mathrm{~mm}, 3-5$-lobed. Cauline leaves usually tri-foliolate, sometimes simple; petiole 1 $10 \mathrm{~mm}$; rachis $(1-) 2-5 \mathrm{~mm}$; petiolule $(0.5-) 1-5 \mathrm{~mm}$ long; terminal leaflet $(4-) 6-9(-13) \times(3-) 8-11(-$ 12) $\mathrm{mm}, 3-5$ lobed, mucronulate at apex. Inflorescence 1 - 2 (-3)-flowered, peduncle up to $6 \mathrm{~cm}$ long; pedicel (0.2-) $0.5-1.5(-3) \mathrm{cm}$ long. Bracts $1-5 \mathrm{~mm}$ long, ovate to lanceolate, entire or 1 - 3-lobed. Flowers (4-) 6 - 8 (10) $\mathrm{mm}$ across. Sepals $4(-5)$, white, tinged purple or light purple. Stamens $8-15$; filaments white to purplish, $(1.5-) 2.5-3(-3.5) \times(0.25-) 0.5-1 \mathrm{~mm}$, widest in the top third. Carpels (2-) $3.5-4.5 \times 0.5-1.1 \mathrm{~mm}$; at base 0.5 - $1.5 \mathrm{~mm}$ stipitate; style (0.4 -) 0.7 - $1.4 \mathrm{~mm}$ long; stigmatic surface along distal (0.3-) $0.5-1 \mathrm{~mm}$ of the style. Achenes falcate, compressed, (2.3-) $3-5.5 \times(0.5-)$ $0.8-1.5 \mathrm{~mm}$; body 3-ribbed, at base $(0.5-) 1-1.8 \mathrm{~mm}$ stipitate; style $(0.5-) 1.2-2 \mathrm{~mm}$ long. Fig. 1 .

DISTRIBUTION. Endemic to New Guinea. Indonesia, Papua Province: Mt Jaya, Orange Mountains, Paniai Lakes. Papua New Guinea: Star Mountains. Map 1.
SPECIMENS EXAMINED: INDONESIA, PAPUA PROVINCE: Wamena, between Habbema and Pabilylo, $3300 \mathrm{~m}$, 19 Oct. 1992, Argent 92490 (E!); Mimika, Freeport Ind. Conc. Area, Meren Valley, 3800 m, 9 March 1998, Baker et al. 934 (K!); Mimika, Freeport Ind. Conc. Area, Mt Idenburg, S slopes, 4000 m, 11 March 1998, Baker et al. 950 (BO!, K!); Mt Jaya, site $87 \mathrm{E}$ of Carstensz Meadow, 3540 m, 21 Nov. 1998, Beaman 12144 (BO!); Mimika, Freeport Ind. Conc. Area, N Canyon, to the E of Bakopa Valley, 3600 m, 20 March 1999, Edwards 4195 (K!); [Paniai] Wissel lakes region, $2900 \mathrm{~m}, 31$ July 1939, Eyma 4987 (BO!); Mt Jaya, W Irian, Carstensz Mts, 3540 m, 13 Dec. 1971, Hope ANU 10844 (CANB!); Mimika, Freeport Ind. Conc. Area, near base of Tramway at Mill Site, $2800 \mathrm{~m}, 18$ March 1999, Johns 9895 (BO!, K!); [Papua, Mt Jaya], Camp XIII - XIV, 13 Jan. 1913, Kloss s.n. (BM!, K!); Valentijn Mts, NE of Koruppun valley, trail from Lake Valley to base camp, 3290 m, 12 Aug. 1988, Mangen 1764 (BO!, GH!); Mt Jaya, W Agawagon Valley, 3230 m, 21 Aug. 1992, Miller 23590 (MU!); ibid., 21 Aug. 1992, Miller 23623 (MU!); Mimika, Freeport Ind. Conc. Area, Pylon, road near Grasberg mine, 3800 m, 6 March 1998, Puradyatmika et al. 10342 (K!); Mimika, Freeport Ind. Conc. Area, Mt Idenburg, S slopes near drill pad, 4000 m, 11 March 1998, Puradyatmika et al. 10372 (BO!, K!); Mt Jaya, Carstensz Meadow, 3400 m, 28 April 1973, Raynal 17347 (K!, P!); Mimika, Freeport Ind. Conc. Area, Wanagon River Valley, 3470 m, 26 April 2000, Utteridge et al. 357 (BO!, K!); Oranje Mts, Waterval biwak, 12 Feb. 1913, Versteeg 2474 (BO!, L!). PAPUA NEW GUINEA, SANDAUN PROVINCE: Telefomin, Star Mts, Tarn in valley, $\mathrm{N}$ of Mt Capella, $3100 \mathrm{~m}, 18$ April 1975, Barker \& Umba LAE 67458 (E!, K!, L!); Telefomin, Sirius Mt, 12 \& 23 April 1965, Craig 56 


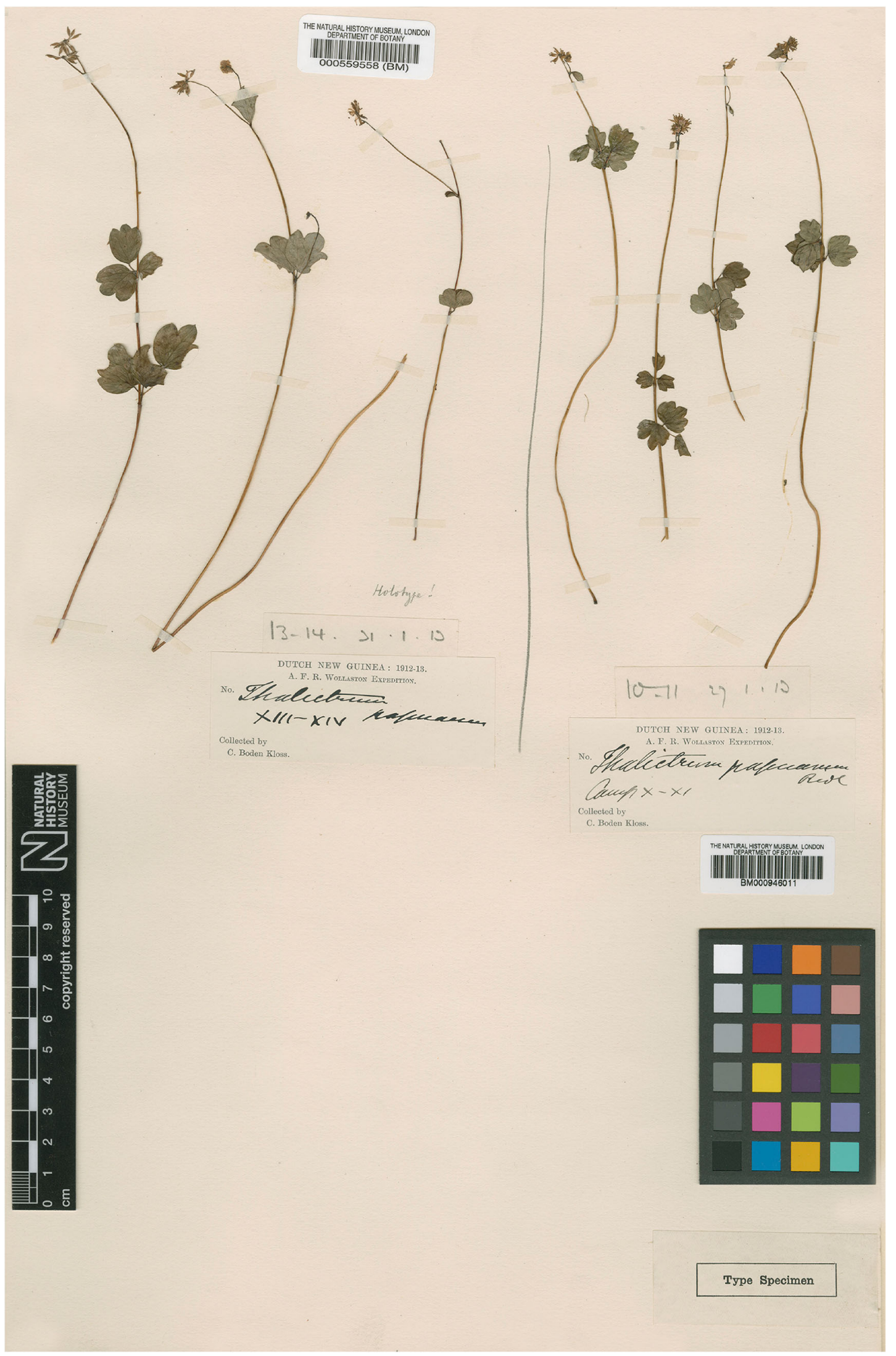

Fig. 1. Holotype of Thalictrum papuanum Ridl. (BM! [BM000559558], (C) The Trustees of the Natural History Museum, London). 


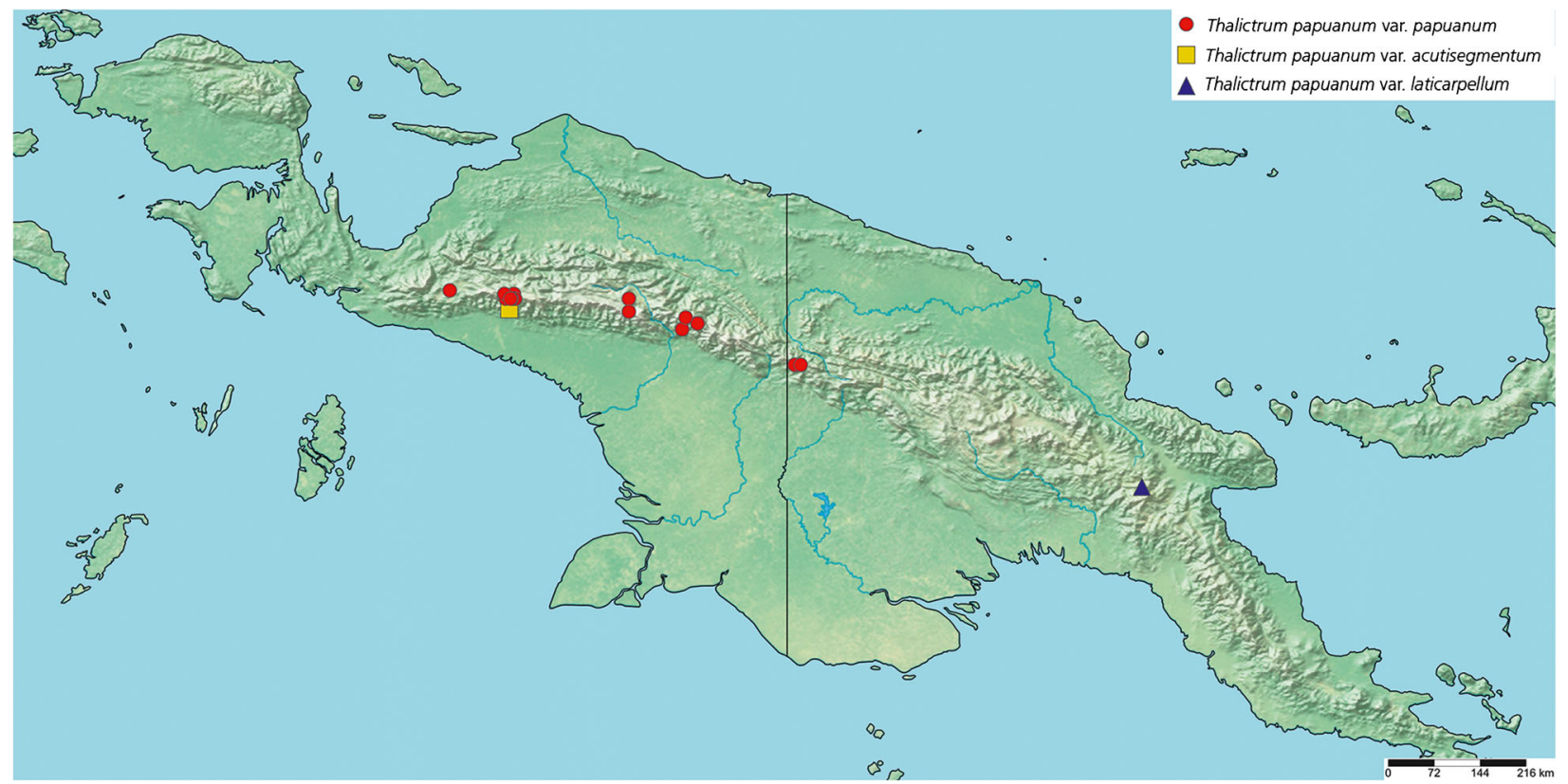

Map 1. Known distribution of Thalictrum papuanum var. papuanum, T. papuanum var. acutisegmentum and T. papuanum var. laticarpellum in New Guinea.

\& 104 (CANB!, LAE!); Star Mts, camp 2, Tel Basin, 2950 m, 9 April 1975, Touw E Veldkamp 6383 (CANB!, L!); Star Mts, camp 10, Dagabulon, 3400 m, 5 May 1975, Veldkamp 6631 (CANB!, K!, L!); Telefomin, top of ridge, track from Tamanagabip to the E end of Mt Capella, 3300 m, 12 April 1975, Vinas LAE 67083 (CANB!).

HABITAT. Upper montane and subalpine forest, subalpine shrubbery, scrub and meadow and alpine grassland. Growing on strongly weathered limestone rocks, in shallow high elevation valleys and on old landslide scars; elevation: $2800-4000 \mathrm{~m}$.

CONSERVATION STATUS. This is a geographically widespread species. The extent of occurrence (EOO) is estimated to be over $39,000 \mathrm{~km}^{2}$. It is inferred from the number of specimen records and the availability of suitable habitat that the area of occupancy (AOO) also exceeds the values needed for a threatened category. This species is therefore assessed as of Least Concern (LC), according to IUCN (2012). The region remains poorly explored botanically and under-collected and field surveys are needed to determine the current distribution, population size and habitat status of this species.

PHENOLOGY. Flowering and fruiting from Feb. to Dec. NOTES. Thalictrum papuanum var. papuanum is distinct on account of the combination of these characters: glabrous herb up to $30 \mathrm{~cm}$ tall with basal leaves usually biternate, sometimes tri-foliolate, filaments $(1.5-) 2.5$ $-3(-3.5) \times 0.5-1 \mathrm{~mm}$, widest in the top third, narrowed at apex and filiform at base, achenes compressed, falcate, $3-5.5 \times(0.5-) 0.8-1.5 \mathrm{~mm}$, at base $(0.5-) 1-1.8 \mathrm{~mm}$ stipitate and with $(0.5-) 1.2$ - 2 mm long style.

Thalictrum papuanum var. oranjense is not recognised as distinct. It was described by Eichler (1958: 7) based on a single collection from the Oranje Mountains [= part of the Jayawijaya range including Mt Trikora], which he stated differed in shorter stem, only up to 10 $\mathrm{cm}$, usually having a single flower, basal leaves usually ternate with shorter leaflets $3 \times 4 \mathrm{~mm}$, cauline leaves ternate to simple, in having fewer stamens, 7 - 12 with smaller filaments $2 \times 0.25 \mathrm{~mm}$ and in having smaller achenes $2.3 \times 0.75 \mathrm{~mm}$. We have found this falls within the variation of the taxon across its range. The taxon is now known to be widely distributed through much of the central mountain range of New Guinea, and the modern collections from Papua New Guinea have expanded the known range. The type locality of Mt Jaya is now positioned centrally within the distribution area.

Thalictrum papuanum Ridl. var. acutisegmentum Borosova var. nov. Type: Indonesia, Papua Province: $\mathrm{N}$ end of Hanekam tunnel, Mt Jaya, 14 Aug. 1998, Marsden 189 (holotype K!).

http:/ /www.ipni.org/urn:lsid:ipni.org:names:77218846-1

Herb, $10-13 \mathrm{~cm}$ tall. Basal leaves $3-7$, blades $1.5-3 \times$ $1.5-3 \mathrm{~cm}$, biternate with 9 leaflets; petiole $(1.5-) 3-$ $4(-7) \mathrm{cm}$ long; rachis $0.5-1 \mathrm{~cm}$ long; petiolule 1 $5 \mathrm{~mm}$ long; terminal leaflet broadly elliptic, rhombicovate or suborbicular, $6-9 \times 5-10 \mathrm{~mm}, 5-7$-lobed. 
HERB. HORT. KEW.

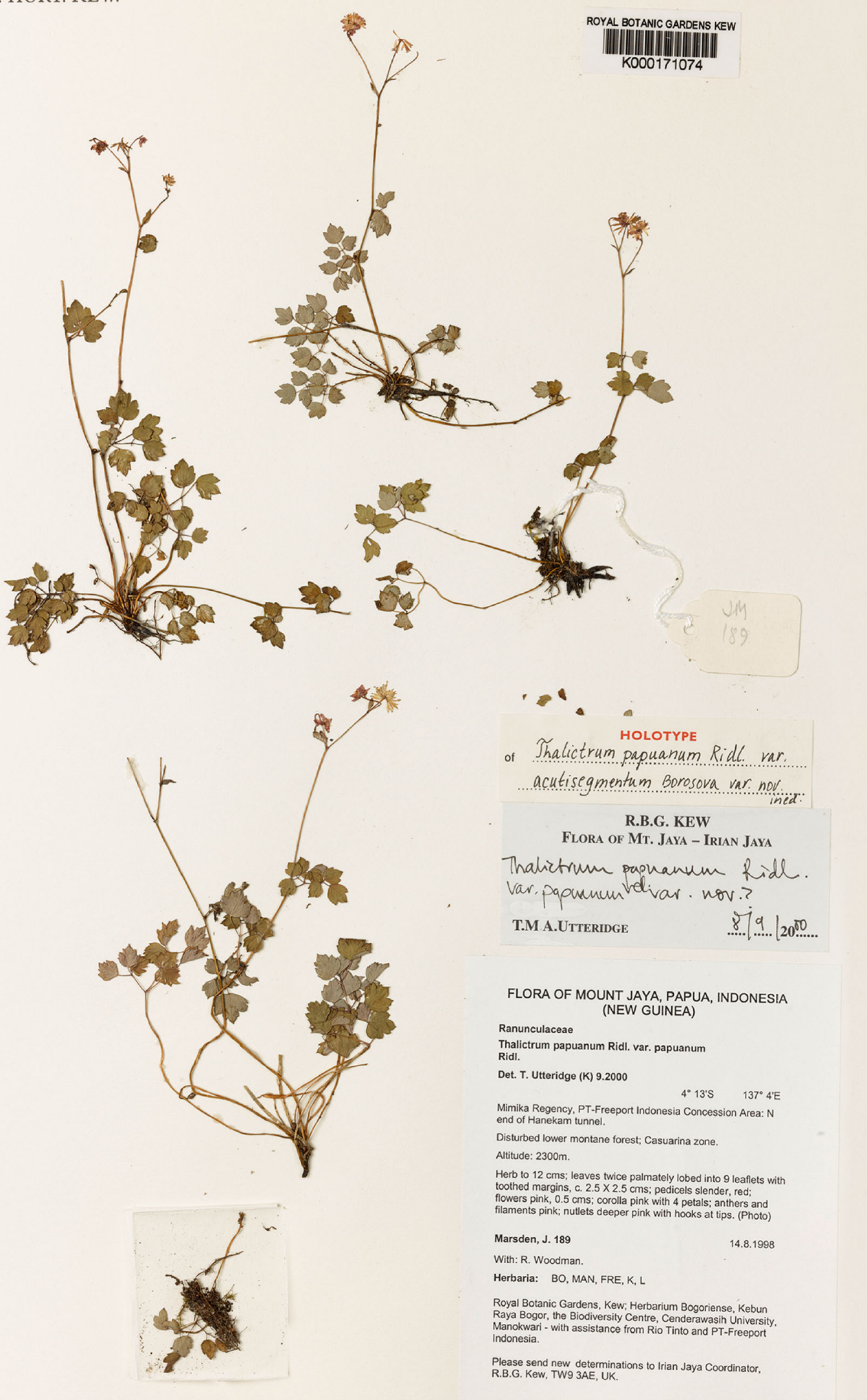

Fig. 2. Holotype of Thalictrum papuanum Ridl. var. acutisegmentum Borosova (K! [K000171074], (C) copyright of the Board of Trustees of the Royal Botanic Gardens, Kew). 
HERB. HORT. KEW.

ROYAL BOTANIC GARDENS KEW

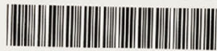

K000575511
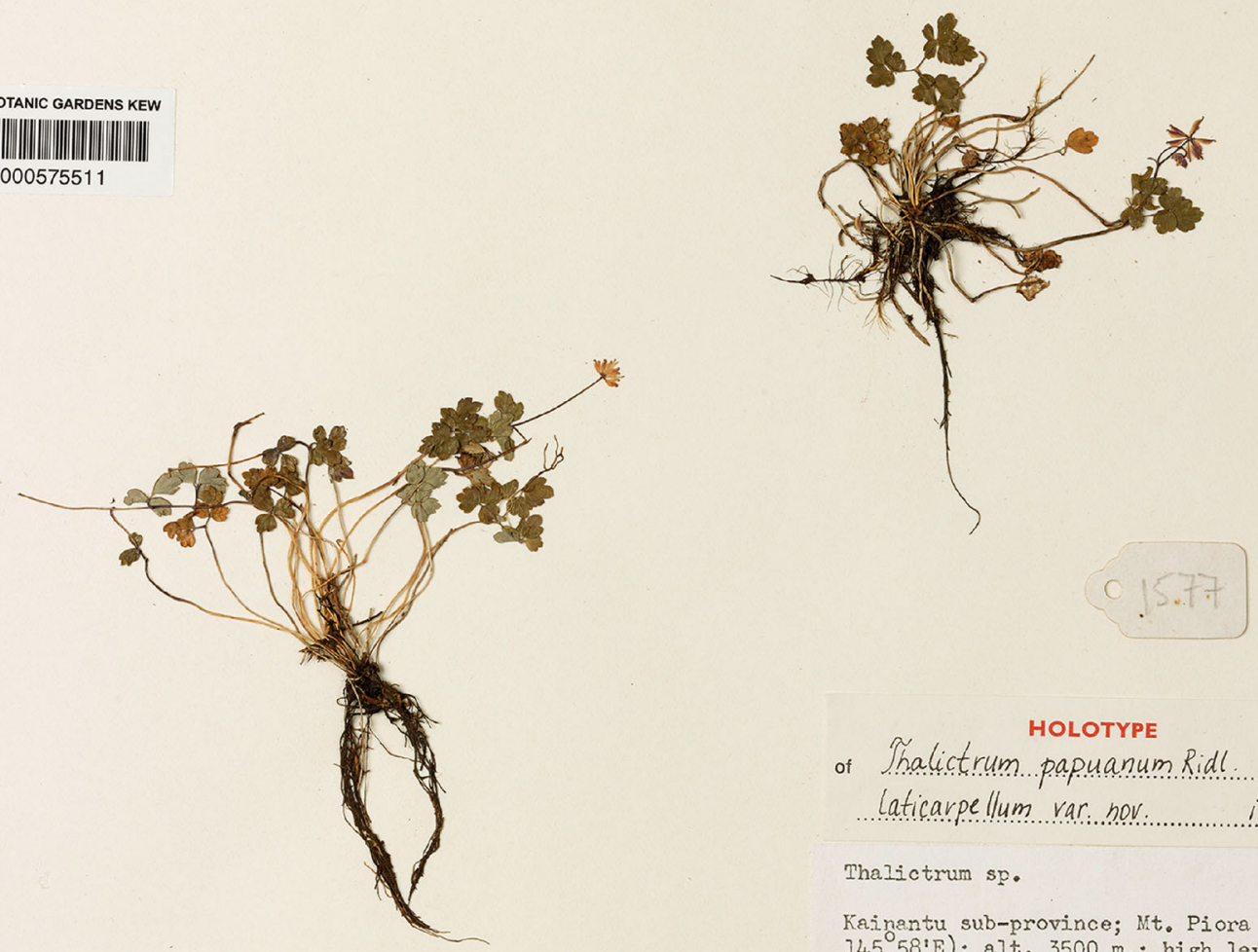

\% HOLOTYPE

of Thalictrum papuanum Ridl var

Laticarpellum var nov. ined.

Thalictrum sp.

Kainantu sub-province; Mt. Piora $\left(6^{\circ} 43^{\prime} \mathrm{S}\right.$ $\left.145^{\circ} 58^{\mathrm{I}} \mathrm{E}\right)$; alt. $3500 \mathrm{~m}$; ; high level areas of sub-alpine tussock heath with scattered Cyathea gleichenioides and scrubby thickets of Ericacea and Dacryocarpus spp. etc.; often subjected to cold, wind, rain and mist; very wet area of tussock heath amongst grass, sphagnum, Gleichenia vulcanica,

Stgphelia suaveolens, Trochocarpa decockii etc.; pH 5.5; growing in moss.

Delicate herb with white filamentous petioles \& $\mathrm{fl}$. stem, purple distally to $3 \mathrm{~cm}$. hight from small white corms; lamina of leaflets dull green above, grey-green beneath; fls. purple.

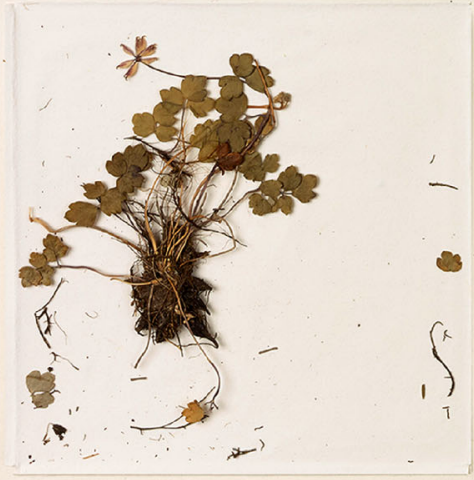

Coll. M.J.S.Sands, G.A.Pattison \& J.J.Wood

31.8 .1975

SANDS 1577

Ŕanume.

HERBARIUM KEWENSE

PAPUA NEW GUINEA

Thalictrum papuanum Ridl.

Det. If Forman Date 1981

EASTERN HIGHLANDS PROVINCE

Date 31.8 .1975 MARTIN J.S. SANDS No. 1577

Royal Botanic Gardens, Kew - Division of Botany, Lae, - 1975 Expedtition

Fig. 3. Holotype of Thalictrum papuanum Ridl. var. laticarpellum Borosova (K! [K000575511], @ copyright of the Board of Trustees of the Royal Botanic Gardens, Kew). 


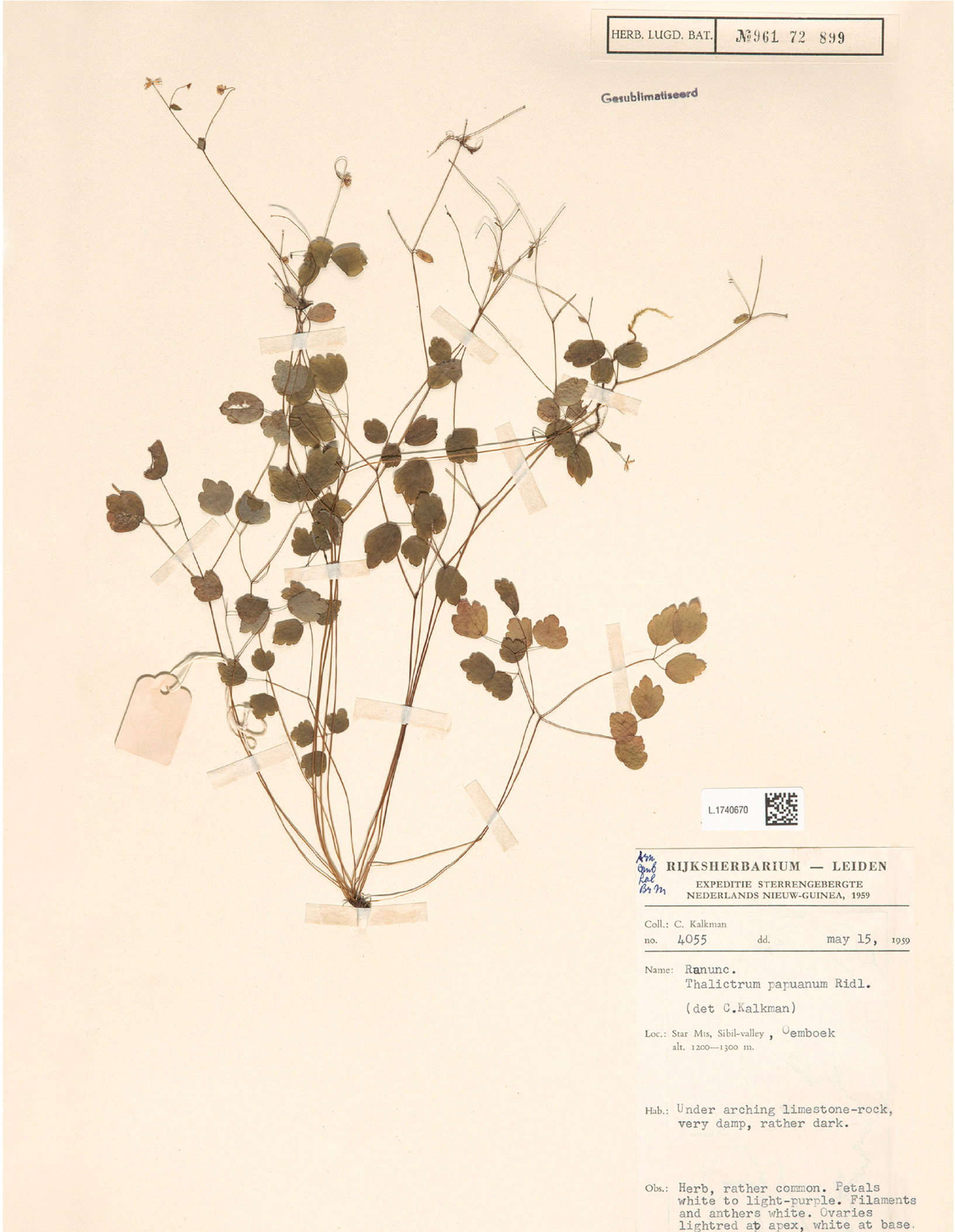

Fig. 4. Holotype of Thalictrum umbraticola Borosova (L! [L1740670], @ Naturalis Biodiversity Center, Leiden, reproduced with permission). 


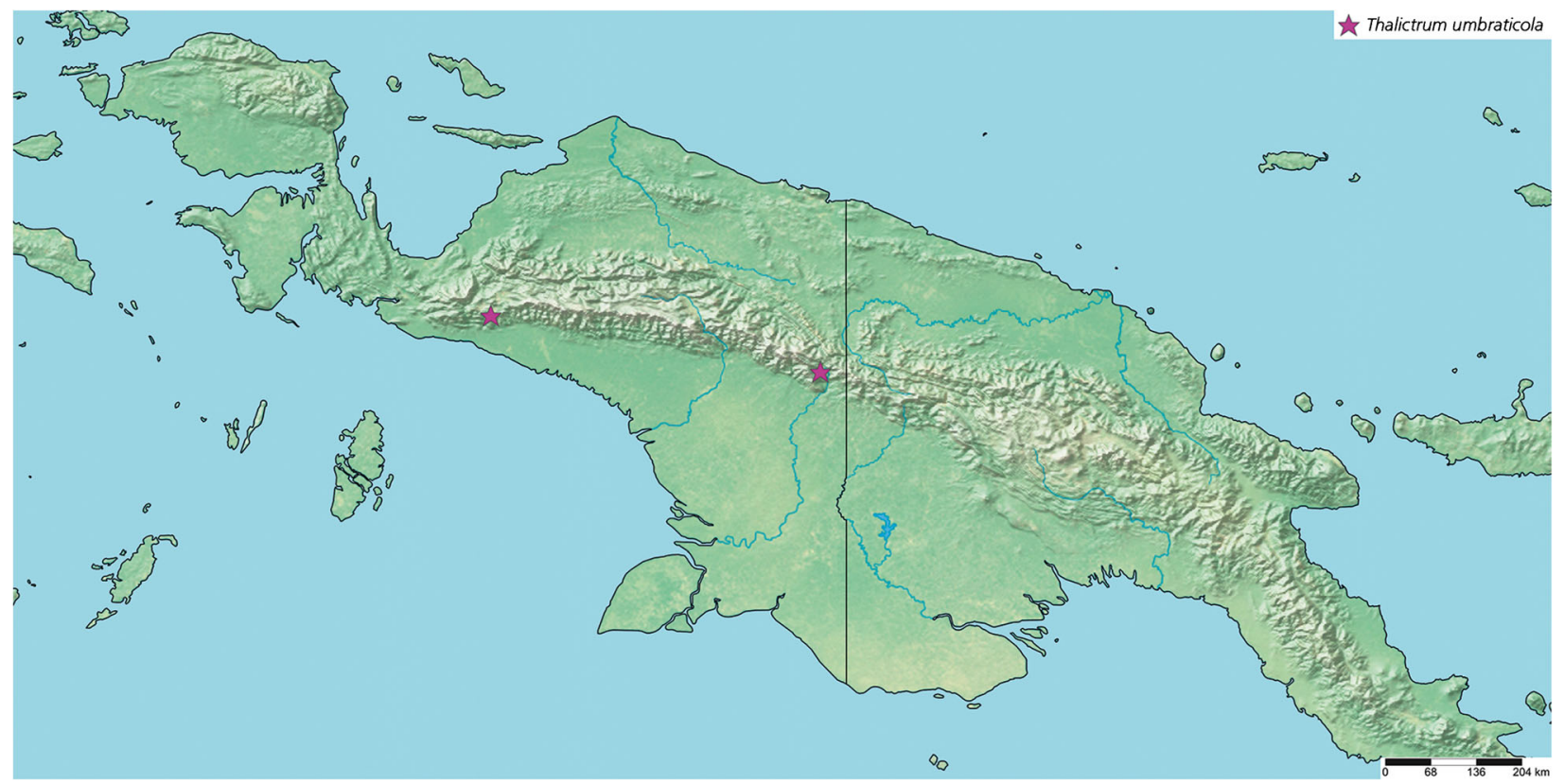

Map 2. Known distribution of Thalictrum umbraticola in New Guinea.

Cauline leaves usually biternate with 9 leaflets; petiole 2 - $5 \mathrm{~mm}$ long; rachis $4-5 \mathrm{~mm}$ long; petiolule $2-4 \mathrm{~mm}$ long; terminal leaflet $6-9 \times 5-9 \mathrm{~mm}$; $(3-) 5(-7)$ lobed, leaflets sharply acuminate to mucronate at apex. Inflorescence 3 (- 4)-flowered, branched; peduncle $2-6 \mathrm{~cm}$ long; pedicel slender, red, $(0.5-) 1-2 \mathrm{~cm}$ long. Bracts $2-5 \mathrm{~mm}$ long, ovate, entire or 1 - 3-lobed. Flowers $4-6 \mathrm{~mm}$ across. Sepals pink. Stamens $15-25$; filaments pink, $2-3 \times 1 \mathrm{~mm}$, widest in the top third. Carpels $4-4.5 \times 0.5-0.7 \mathrm{~mm}$; at base c. $1.5 \mathrm{~mm}$ stipitate; style $0.8-1.2 \mathrm{~mm}$ long; stigmatic surface along distal 0.5 $-1 \mathrm{~mm}$ of the style. Achenes falcate, strongly compressed, $4-5 \times 0.5-0.8 \mathrm{~mm}$, body 3 -ribbed, at base $1.5-2 \mathrm{~mm}$ stipitate; style $1-1.5 \mathrm{~mm}$ long. Fig. 2.

RECOGNITION. This variety is unique in the following combination of characters: $10-13 \mathrm{~cm}$ tall herb, cauline leaves usually biternate with 9 leaflets, leaflets sharply acuminate to mucronate at apex, inflorescence $3(-4)$ flowered and achenes up to $0.8 \mathrm{~mm}$ wide.

DISTRIBUTION. Endemic to Papua Province in Indonesia, and currently only known from the type collected from the northern end of the Hanekam Tunnel in the Mt Jaya region. Map 1.

SPECIMEN EXAMINED. INDONESIA, Papua Province: N end of Hanekam tunnel, Mt Jaya, 14 Aug. 1998, Marsden 189 (holotype K!).

HABITAT. Disturbed lower montane forest, Casuarina zone; elevation: $2300 \mathrm{~m}$.

CONSERVATION STATUS. Since there is only one collection of this variety and in the absence of information on threats, a conservation category of Data Deficient
(DD) is proposed for this variety. Further field surveys in the area are recommended.

PHENOLOGY. Collected flowering and fruiting in Aug. ETYMOLOGY. From the Latin acutus, pointed, and segmentum, segment, referring to the sharply acuminate apices of the leaflets.

NOTES. The new variety described here, Thalictrum papuanum var. acutisegmentum, is morphologically similar to T. papuanum var. papuanum in its overall size, having basal leaves biternate with similar size leaflets, filaments the same shape and size and achenes strongly compressed, falcate, long stipitate and with style circinnate.

Thalictrum papuanum var. acutisegmentum is recognised by sharply acuminate leaflets, biternate cauline leaves, 3 (- 4)-flowered inflorescence and narrower achenes. The description is based on the study of several duplicates of a single collection. This combination of characters was only observed in these specimens and not in any other collections studied. However, since there is some overlap in characters with var. papuanum, more collections are needed to determine if this taxon is sufficiently distinct to be recognised at species level.

Thalictrum papuanum Ridl. var. laticarpellum Borosova var. nov. Type: Papua New Guinea, Mt Piora, Eastern Highlands Province, 31 Aug. 1975, Sands 1577 (holotype $\mathrm{K}$ !).

http:/ /www.ipni.org/urn:lsid:ipni.org:names:77218847-1 
Delicate herb, $5-7 \mathrm{~cm}$ tall. Basal leaves $5-9$, blades $1.2-1.8$ $\times 0.8-2 \mathrm{~cm}$, biternate with 9 leaflets; petiole $(1-) 1.5-3$ (4) $\mathrm{cm}$, white, filamentous; rachis $2-5 \mathrm{~mm}$ long; petiolule 1 - $3 \mathrm{~mm}$ long; terminal leaflet broadly elliptic, rhombicovate or suborbicular, 3-6×3-6 mm,3-5-lobed. Cauline leaves biternate with 9 leaflets, rarely tri-foliolate; petiole 2 $5 \mathrm{~mm}$; rachis $4-5 \mathrm{~mm}$; petiolule $2-4 \mathrm{~mm}$; terminal leaflet $3-6 \times 3-6 \mathrm{~mm} ; 3-5$-lobed, prominently veined, mucronulate at apex. Inflorescence 1 - 2-flowered; peduncle $4-6 \mathrm{~cm}$ long, slender, purple distally to $3 \mathrm{~cm}$ high from small white corms; pedicel $0.7-0.8 \mathrm{~cm}$ long. Bracts $2 \mathrm{~mm}$ long, lanceolate, entire. Flowers c. $6 \mathrm{~mm}$ across. Sepals purple. Stamens $5-10$; filaments $3 \times 0.5 \mathrm{~mm}$, widest in the top third. Carpels $3-3.5 \times 1-1.5 \mathrm{~mm}$; at base up to $1 \mathrm{~mm}$ stipitate; style 0.8 - $1.2 \mathrm{~mm}$ long; stigmatic surface along distal $0.5-1 \mathrm{~mm}$ of the style. Achenes obovate to lanceolate, strongly compressed, $4 \times 1.5 \mathrm{~mm}$, body 3 -ribbed, base up to $1 \mathrm{~mm}$ stipitate; style $1 \mathrm{~mm}$ long. Fig. 3.

RECOGNITION. This variety is unique in the following combination of characters:

Delicate, $5-7 \mathrm{~cm}$ tall herb, cauline leaves usually biternate with 9 leaflets, terminal leaflets of basal and cauline leaves the same size $3-6 \times 3-6 \mathrm{~mm}$, mucronulate at apex, inflorescence 1 - 2-flowered, achenes obovate to lanceolate, up to $1 \mathrm{~mm}$ stipitate, $1.5 \mathrm{~mm}$ wide.

DIStRIBUtion. Endemic to Papua New Guinea, Mt Piora. Map 1.

SPECIMEN EXAMINED. PAPUA NeW GUINEA, Mt Piora, Eastern Highlands Province, 31 Aug. 1975, Sands 1577 (holotype K!).

HABITAT. High level areas of sub-alpine tussock heath; elevation: $3500 \mathrm{~m}$.

CONSERVATION STATUS. Since there is only one collection of this variety and in the absence of information on threats, a conservation category of Data Deficient (DD) is proposed for this variety. Further survey in the area is recommended.

PHENOLOGY. Collected flowering and fruiting in Aug. ETYMOLOGY. From the Latin latus, broad, and carpellum, carpel, referring to the broader carpels compared with the other varieties.

NOTES. This new variety, Thalictrum papuanum var. laticarpellum, is morphologically similar to T. papuanum var. papuanum in its overall size, having basal leaves biternate, filaments the same shape and size and achenes strongly compressed, stipitate and with circinnate style. Thalictrum papuanum var. laticarpellum is recognised by its terminal leaflets of basal and cauline leaves being the same size $(3-6 \times 3-6 \mathrm{~mm})$ and mucronulate at the apex, having a 1 - 2-flowered inflorescence, achenes obovate to lanceolate, up to $1 \mathrm{~mm}$ stipitate and $1.5 \mathrm{~mm}$ wide. This combination of characters was only observed in these specimens and not in any other collections studied.
Thalictrum umbraticola Borosova sp. nov. Type: Indonesia. Papua Province: Star Mts, Sibil Valley, Oemboek, 15 May 1959, Kalkman 4055 (holotype L!; isotypes BM!, CANB!, GH!).

http://www.ipni.org/urn:lsid:ipni.org:names:77218848-1

Glabrous herb; (20 -) 25 - $40 \mathrm{~cm}$ tall. Roots fibrous, rhizome slender. Stems erect, branched. Basal leaves $6-10$, blades $3-7 \times 3-9 \mathrm{~cm}$, biternate with 9 leaflets; petiole $4-12 \mathrm{~cm}$; rachis $1-4.5 \mathrm{~cm}$ long; petiolule $0.3-1 \mathrm{~cm}$ long; terminal leaflet broadly elliptic, ovate or suborbicular, $(9-) 11-18 \times(8-)$ 10 - 15 (-18) mm, 5 (-7)-lobed. Cauline leaves 1 2, alternate, tri-foliolate, rarely biternate with 9 leaflets or simple; petiole $13-23 \mathrm{~mm}$; rachis (if present) and petiolules 5 - $15 \mathrm{~mm}$ long; terminal leaflet broadly elliptic to orbicular ovate, $9-13$ (15) $\times 9-12(-16) \mathrm{mm}, 3-7$-lobed, prominently palmately 3 - 5-veined, base rounded, sometimes cuneate to subcordate, apex mucronulate, margin slightly revolute. Inflorescence racemose, 4 - 6-flowered, branched; peduncle (4-) 8 - 13 cm long; pedicel erect or slightly recurved, (0.5 -) $1-3$ (4) $\mathrm{cm}$ long. Bracts $1-2$, leaf-like, $4-13(-15) \mathrm{mm}$ long, ovate to lanceolate, entire or lobed. Flowers $(3.5-) 4-5.5 \mathrm{~mm}$ across. Sepals 4 , ovate to elliptic, $2 \times 1 \mathrm{~mm}$, white to light purple. Stamens $8-15$; filaments white, $(1.5-) 2-2.5 \times 0.2-0.5 \mathrm{~mm}$, widest in the top third, base filiform, apex narrowly linear, narrower than anther. Anther $0.5 \mathrm{~mm}$ long, obtuse at apex, connectives not projected. Carpels 6 -9 , erect, white at base, light red at apex, $2.5-3 \times$ $0.5 \mathrm{~mm}$, fusiform; at base $0.5-1 \mathrm{~mm}$ stipitate; style linear, coiling inwards, $1-1.5 \mathrm{~mm}$ long; stigmatic surface along distal $0.5-0.8 \mathrm{~mm}$ of the style. Achenes 6 - 9, erect at first, later curving downwards, fusiform, falcate, strongly compressed, $3.5-$ $5.5 \times 0.5 \mathrm{~mm}$, body 1 - 2-ribbed, dorsal suture usually straight, \ventral suture usually convex, 0.5 $1 \mathrm{~mm}$ stipitate; style $1.5-2 \mathrm{~mm}$ long, circinnately coiled inwards. Fig. 4.

RECOGNITION. Thalictrum umbraticola is unique in the following combination of characters: style circinnately coiled inwards at apex, $6-9$ achenes, 1 - 2-ribbed on each side, $3.5-5.5 \times 0.5 \mathrm{~mm}$, basal leaves few, blades up to $9 \mathrm{~cm}$ long with leaflets up to $1.8 \mathrm{~cm}$ long and it grows at relatively low elevations $(1200-1300 \mathrm{~m})$, under arching limestone rock, in very damp and rather dark habitat. DISTRIBUTION. Endemic to West Papua; Star Mountains (Sibil valley, Oemboek) and Paniai lakes. Map 2.

SPECIMENS EXAMINED. INDONESIA: [Paniai] Wissel lake region, biv. 12 - 14, [1200 m], 7 Jan. 1939, Eyma 4248 (BO!, K!, L!); Star Mts, Sibil valley, Oemboek, 1200 - 
1300, 15 May 1959, Kalkman 4055 (BM!, CANB!, GH!, L!).

HABITAT. Under arching limestone rock, very damp, rather dark, lower montane forest; elevation: 1200 $1300 \mathrm{~m}$.

CONSERVATION STATUS. Due to sparsity of herbarium material and in the absence of information on threats, a conservation category of Data Deficient (DD) is proposed for this species; having only two collections does not allow us to calculate EOO or AOO. Further surveys in the area are recommended.

PHENOLOGY. Flowering and fruiting from Jan. to May. ETYMOLOGY. From the Latin umbra, shade, and -cola, dweller, referring to the shady habitat of this species. NOTES. Thalictrum umbraticola is morphologically close to $T$. javanicum Blume and T. uncatum Maxim. (as delimited by Zheng et al. 2018) in height, glabrous habit and styles hooked at apex. It differs conspicuously from $T$. javanicum in the basal leaves (T. umbraticola biternate vs $T$. javanicum $3-4$ ternate), stipitate achenes (stipe $0.5-1 \mathrm{~mm}$ vs achenes sessile) and style length ( $1-2 \mathrm{~mm}$ vs $0.6-1 \mathrm{~mm}$ ); and from T. uncatum in leaf blade size $(3-7 \times 3-9 \mathrm{~cm}$ vs $9.5-$ $13 \times 15 \mathrm{~cm})$ and style length $(1-2 \mathrm{~mm}$ vs $2.2-3 \mathrm{~mm})$. It differs from both in the smaller sepals $(2 \times 1 \mathrm{~mm})$, fewer stamens (15), shorter filaments ((1.5-) $2-2.5)$, shorter anthers $(0.5 \mathrm{~mm})$ and fewer carpels $(6-9)$.

\section{Acknowledgements}

We thank the curators and staff of the following herbaria for access to or loan of material and their assistance: Jacek Wajer (BM), staff of Herbarium Bogoriense (BO), Brendan Lepschi (CANB), Erzsébet Gyöngy (E), Anthony R. Brach (GH), Nicolien Sol (L), Tiberius Jimbo and Thomas Magun (LAE), Odile Weber (LUX), Dr Michael A. Vincent (MU), Florian Jabbour (P) and Serena Lee M.L. (SING). The comments and suggestions of two anonymous reviewers were extremely useful and we thank them for helping to improve the manuscript; we also thank Carmen Puglisi for useful discussions and constructive comments.

Open Access This article is licensed under a Creative Commons Attribution 4.0 International License, which permits use, sharing, adaptation, distribution and reproduction in any medium or format, as long as you give appropriate credit to the original author(s) and the source, provide a link to the Creative Commons licence, and indicate if changes were made. The images or other third party material in this article are included in the article's Creative Commons licence, unless indicated otherwise in a credit line to the material. If material is not included in the article's Creative Commons licence and your intended use is not permitted by statutory regulation or exceeds the permitted use, you will need to obtain permission directly from the copyright holder. To view a copy of this licence, visit http://creativecommons.org/ licenses/by/4.0/.

\section{References}

Aitzetmüller, K. (1994). Fatty acid patterns of Ranunculaceae seed oils: phylogenetic relationships. In: U. Jensen \& J. W. Kadereit (eds), Systematics and Evolution of the Ranunculiflorae, pp. 229 - 240. Springer, Vienna. [Pl. Syst. Evol. Suppl. 9.]

Akeroyd, J. R. (1993). Thalictrum. In: T. G. Tutin, N. A. Burges, A. O. Chater, J. R. Edmondson, V. H. Heywood, D. M. Moore, D. H. Valentine, S. M. Walters \& D. A. Webb (eds), Flora Europaea, ed. 2, 1: 290 - 292. Cambridge University Press, Cambridge.

Bachman, S., Moat, J., Hill, A.W., De Torre, J. \& Scott, B. (2011). Supporting Red List threat assessments with GeoCAT: geospatial conservation assessment tool. ZooKeys (150): 117 - 126.

Beentje, H. (2016). The Kew Plant Glossary: An Illustrated Dictionary of Plant Terms - Second edition. Royal Botanic Gardens, Kew.

Cámara-Leret, R., Frodin, D. G., Adema, F., Anderson, C., Appelhans, M. S., Argent, G., Guerrero, S. A., Ashton, P., Baker, W. J., Barfod, A. S., Barrington, D., Borosova, R., Bramley, G. L. C., Briggs, M., Buerki, S., Cahen, D., Callmander, M. W., Cheek, M., Chen, C.-W., Conn, B. J., Coode, M. J. E., Darbyshire, I., Dawson, S., Dransfield, J., Drinkell, C., Duyfjes, B., Ebihara, A., Ezedin, Z., Fu, L.-F., Gideon, O., Girmansyah, D., Govaerts, R., FortuneHopkins, H., Hassemer, G., Hay, A., Heatubun, C. D., Hind, D. J. N., Hoch, P., Homot, P., Hovenkamp, P., Hughes, M., Jebb, M., Jennings, L., Jimbo, T., Kessler, M., Kiew, R., Knapp, S., Lamei, P., Lehnert, M., Lewis, G. P., Linder, H. P., Lindsay, S., Low, Y. W., Lucas, E., Mancera, J. P., Monro, A. K., Moore, A., Middleton, D. J., Nagamasu, H., Newman, M. F., Nic Lughadha, E., Melo, P. H. A., Ohlsen, D. J., Pannell, C. M., Parris, B., Pearce, L., Penneys, D. S., Perrie, L. R., Petoe, P., Poulsen, A. D., Prance, G. T., Quakenbush, J. P., Raes, N., Rodda, M., Rogers, Z. S., Schuiteman, A. Schwartsburd, P., Scotland, R. W., Simmons, M. P., Simpson, D. A., Stevens, P., Sundue, M., Testo, W., Trias-Blasi, A., Turner, I., Utteridge, T. M. A., Walsingham, L., Webber, B. L., Wei, R., Weiblen, G. D., Weigend, M., Weston, P., de Wilde, W., Wilkie, P., Wilmot-Dear, C. M., Wilson, H. P., Wood, J. R. I., Zhang, L.-B. \& van Welzen, P. C. (2020). New Guinea has the world's richest island flora. Nature 584: 579 - 583.

Chen, G., Ramachandran, C. \& Krishan, A. (1993). Thaliblastine, a plant alkaloid, circumvents multi- 
drug resistance by direct binding to P-glycoprotein. Cancer Res. 53: $2544-2547$.

Culham, A. (2007). Ranunculaceae. In: V. H. Heywood, R. K. Brummitt, A. Culham, \& O. Seberg (eds), Flowering Plant Families of the World, pp. 273 276. Royal Botanic Gardens, Kew.

Eichler, H. (1958). Revision der Ranunculaceen Malesiens. Biblioth. Bot. 124: 1 - 110.

Fu, D. Z. \& Zhu, G. (2001). Thalictrum. In: Z. Y. Wu \& P. H. Raven (eds), Fl. China 6: 282 - 302. Science Press, Beijing, and Missouri Botanical Garden Press, St. Louis.

IUCN (2012). IUCN Red List Categories and Criteria: Version 3.1. Second Edition. IUCN, Gland and Cambridge. Available from: http:// www.iucnredlist.org/ Accessed Aug. 2020.

Jarvis, C. E. (1993). Order out of chaos. Linnean plant names and their types. The Linnean Society of London.

Linnaeus, C. (1753). Species Plantarum. Holmiae, Stockholm.

(1754). Genera Plantarum, fifth edition. Holmiae, Stockholm.

Mabberley, D. J. (2008). Mabberley's Plant-Book. Third edition. Cambridge University Press, New York.

Mangen, J.-M. (1993). Ecology and Vegetation of Mt Trikora, New Guinea (Irian Jaya/Indonesia). Trav. Sci. Mus. Natl. Hist. Nat. Luxembourg 21: 1 216.

Pajeva, I., Todorov, D. K. \& Seydel, J. (2004). Membrane effects of the antitumor drugs doxorubicin and thaliblastine: comparison to multidrug resistance modulators verapanil and transflupentixol. Eur. J. Pharm. Sci. 21: 243 - 250.

Park, M. M. \& Festerling, D. Jr. (1997). Thalictrum. In: Editorial Committee, Flora of North America North of Mexico 3: 258 - 271. Oxford University Press, New York and Oxford.

Park, S. \& Park, S. J. (2008). The morphology of Thalictrum L. in Korea. Korean J. Pl. Taxon. 38: $433-458$. \& _ (2009). Systematics of Korean Thalictrum L. based on a morphological cladistic analysis. Korean J. Pl. Taxon. 39: 89 - 99.

Plants of the World Online (POWO) (2019). Facilitated by the Royal Botanic Gardens, Kew. Published on the Internet; http:/ / www.plantsoftheworldonline.org/ Retrieved 26 March 2020.

Rau, M. A. (1993). Thalictrum. In: B. D. Sharma, N. P. Balakrishnan, R. R. Rao \& P. K. Hajra (eds), Flora of India 1, pp. 132 - 143. Botanical Survey of India, Calcutta.

Ridley, H. N. (1916). Report on the Botany of the Wollaston Expedition to Dutch New Guinea, 1912 13. Trans. Linn. Soc. London, Bot. 9: 1 - 269.
Riedl, H. (1992). Thalictrum. In: K. H. Rechinger, Flora Iranica 171: 114 - 126. Akademische Druck- u. Verlagsanstalt, Graz.

\& Nasir, Y. J. (1991). Thalictrum. In: S. I. Ali \& J. N. Yasin (eds), Flora of Pakistan 193 Ranunculaceae, pp. 95 - 111. University of Karachi.

Royen, P. van (1982). Ranunculaceae. Alpine Flora of New Guinea 3: 1289 - 1366. A. R. Gantner Verlag K. G., Vaduz.

Shorthouse, D. P. (2010). SimpleMappr, an online tool to produce publication-quality point maps. [Retrieved from https://www.simplemappr.net. Accessed Nov. 2019]

Soza, V. L., Brunet, J., Liston, A., Salles Smith, P. \& Di Stilio, V. S. (2012). Phylogenetic insights into the correlates of dioecy in meadow-rues (Thalictrum, Ranunculaceae). Molec. Phylogenet. Evol. 63: 180 - 192.

Stace, C. (1997). Thalictrum. New Flora of the British Isles, second edition. Cambridge University Press, Cambridge.

Stevens, P. F. (2001 onwards). Angiosperm Phylogeny Website. Version 14, July 2017 (continuously updated) http:/ / www.mobot.org/MOBOT/research/ APweb. Accessed Aug. 2020.

Tamura, M. (1993). Thalictrum. In: K. Kubitzki (ed.), The Families and Genera of Vascular Plants. II. Flowering Plants: Dicotyledons, Magnoliid, Hamamelid and Caryophyllid Families, pp. 581 - 582. Springer Verlag, Berlin, Heidelberg.

(1995). Ranunculaceae. In: P. Hiepko (ed.), Die Natürlichen Pflanzenfamilien, Band 17 a IV: 223 519. Duncker \& Humblot, Berlin.

(2011). Ranunculaceae. In: K. Larsen et al. (eds), Fl. Thailand 11 (1): 48 - 68. Bangkok Forest Herbarium, Bangkok.

Thiers, B. (continuously updated). Index Herbariorum: A global directory of public herbaria and associated staff. New York Botanical Garden's Virtual Herbarium. Available from: http://sweetgum.nybg.org/ih/. Accessed Nov. 2019.

Turland, N. J., Wiersema, J. H., Barrie, F. R., Greuter, W., Hawksworth, D. L., Herendeen, P. S., Knapp, S., Kusber, W.-H., Li, D.-Z., Marhold, K., May, T. W., McNeill, J., Monro, A. M., Prado, J., Price, M. J. \& Smith, G. F. (eds) (2018). International Code of Nomenclature for algae, fungi, and plants (Shenzhen Code) adopted by the Nineteenth International Botanical Congress Shenzhen, China, July 2017. Regnum Veg. 159. Koeltz Botanical Books, Glashütten.

Utteridge, T. M. A. (2006). Ranunculaceae. In: R. J. Johns, P. J. Edwards, T. M. A. Utteridge \& H. F. Hopkins, $A$ Guide to the Alpine and Subalpine Flora of Mount Jaya, pp. 412 - 418. Royal Botanic Gardens, Kew. 
Wang, W. T. (2018). Thalictrum (Ranunculaceae) in China. Peking University Press, Beijing.

, Lu, A.-M., Ren, Y., Endress, M. E. \& Chen, Z.-D. (2009). Phylogeny and classification of Ranunculales: Evidence from four molecular loci and morphological data. Perspect. Pl. Ecol. Evol. Syst. 11: $81-110$.

Zheng, Y.-P., Yuan, Q. \& Yang, Q.-E. (2018). Reinstatement of the independent specific status of Thalictrum hamatum (Ranunculaceae), with T. macrorhynchum reduced to its synonymy.
Phytotaxa 369 (4): 278 - 286.

Ziman, S. N. \& Keener, C. S. (1989). Geographical analysis of the family Ranunculaceae. Ann. Missouri Bot. Gard. 76: 1012 - 1049.

\section{Publisher's Note}

Springer Nature remains neutral with regard to jurisdictional claims in published maps and institutional affiliations. 